\title{
U.S. Geological Survey Programs in Puerto Rico
}

\section{U.S. Department of the Interior - U.S. Geological Survey}

For more than 100 years, the U.S. Geological Survey (USGS) has been mapping, describing, and seeking to understand the Nation's natural resources. The USGS is known for impartial data collection and interpretation that enables resource planners and others to make informed decisions. Today's issues are more pressing than ever-understanding natural hazards to minimize their effects on life and property, the continuing need for mineral- and waterresource development, and understanding the effects of human activities on water and biological resources.

\section{As the Nation's lead natural science} agency, the USGS works with Commonwealth and other Federal agencies in addressing these issues in Puerto Rico. USGS maps, interpretive reports, and data are used by educators; municipalities; various local and Federal planning agencies; consulting firms; farmers; and other private citizens to manage Puerto Rico's resources.

\section{High-Energy Storms}

Though frightening and economically damaging, hurricanes and other high-energy storms are vital to the long-term health of delicate marine and terrestrial ecologies in coastal areas (fig. 1). Marine geologists of the USGS working in the Commonwealth of Puerto Rico are confident that the long-term effects of Hurricane Hugo on the coastal environment are minimal, although the economic damage was significant. As part of the continuing research conducted in Puerto Rico, the shelf area offshore of the town of Luquillo was mapped using high-resolution sonar, seismic-reflection profiles, photographs, and bottom sampling following the passage of Hurricane Hugo. Sea-floor structure, local geology, and sediment characteristics indicate that a regional cross-shelf transport of sand occurs during storms, but that it is trapped by ridges to form sand deposits as much as 60 feet thick. Sand eroded from the beach front moves offshore, and the pathways for that movement can be documented by using remote imagery.

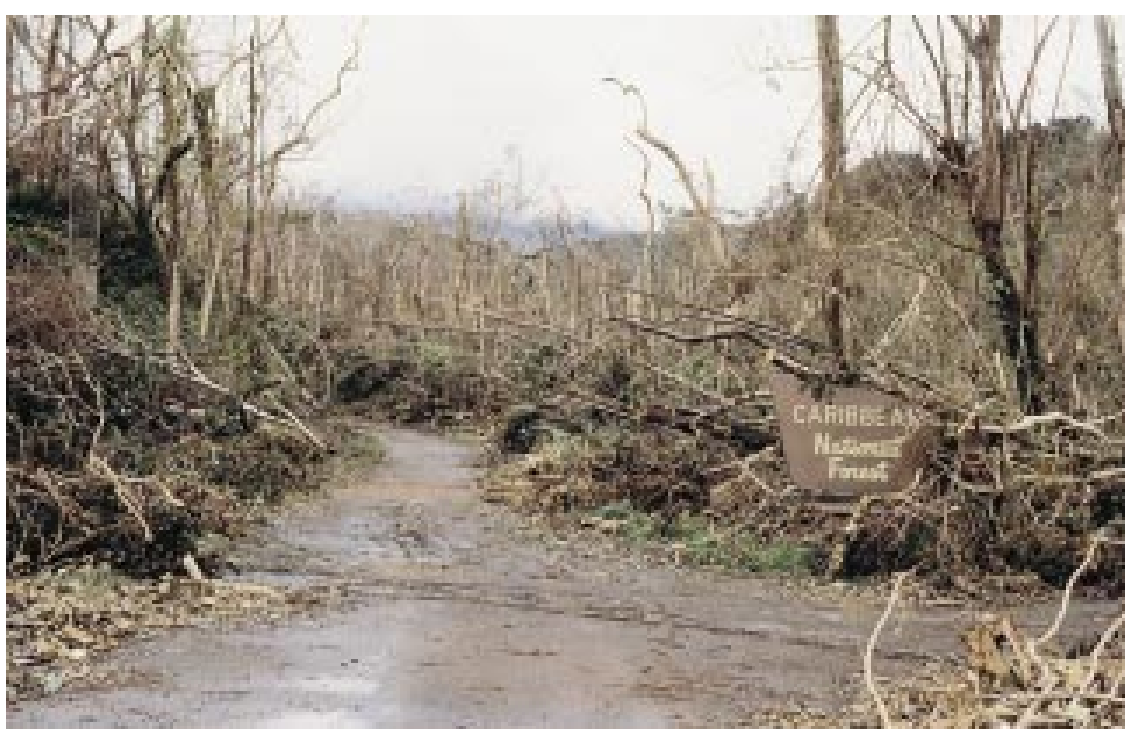

Figure 1. The entrance to the Caribbean National Forest (CNF) in northeastern Puerto Rico three days after the passage of Hurricane Hugo on September 18, 1989. Tree mortality was reported to be as high as 35 percent in the northeastern part of the CNF.

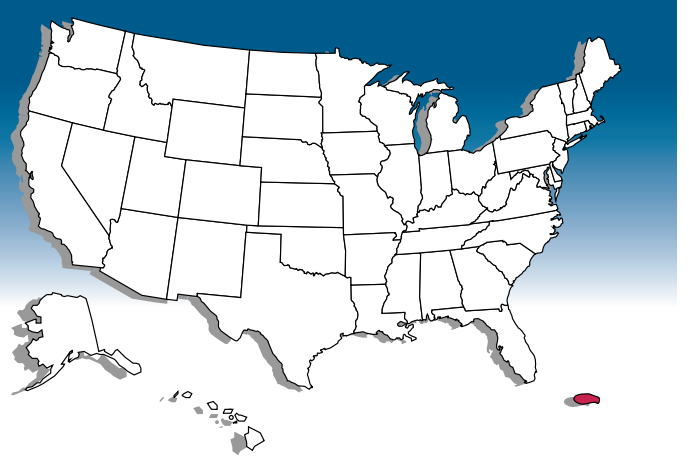

Index of Subjects

High-Energy Storms

Assessing Landslide Hazards

Beach Erosion and Coastal Development at Rincón, Puerto Rico

Hydrologic Data Collection

Floods and Droughts

Water, Energy, and Biogeochemical Budgets

Topographic Mapping

Geologic Mapping

Earth Observation Data

\section{Assessing Landslide Hazards}

High-energy storms also can bring large amounts of rainfall in very short periods of time to mountainous regions of Puerto Rico. These events can trigger hundreds of landslides, which are common in the mountainous areas of Puerto Rico where mean annual rainfall and the frequency of intense storms are high, and hillslopes are steep (fig. 2). Each year, landslides cause extensive damage to property and occasionally result in

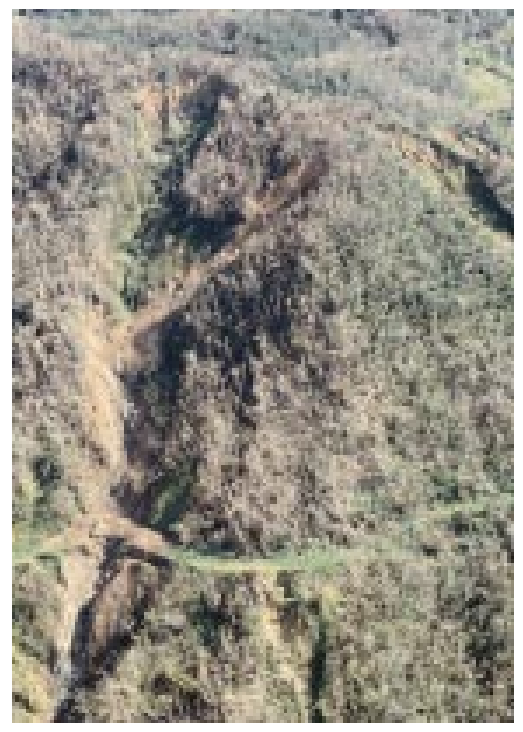

Figure 2. Two debris avalanche scars along Highway PR191 in the Sierra de Luquillo, Puerto Rico, measuring 600 meters from the ridge top to the two-lane highway visible in the foreground. The avalanches were triggered by intense precipitation in 1970 and 1989 with rainfall totals of 300 to 900 millimeters. 
loss of life. Population density in Puerto Rico is high, 400 people per square kilometer, and is increasing. This increase is accompanied by the use of less desirable construction sites. As a result, human populations are becoming more vulnerable to landslide hazards.

The principal objective of a 3-year USGS study in the Río Blanco, the Río Cibuco, and the Río Coamo Basins was to evaluate the geographic relations of landslide distribution across the range of topography, climate, soils, and bedrock geology that occur in Puerto Rico (fig. 3). An additional objective was to determine the rainfall accumulation and duration characteristics of storms likely to trigger landslides in the central mountains of the island and to develop a rainfall accumulation/duration threshold relation for Puerto Rico.

Study results indicate that landslides in the Sierra de Luquillo and the Sierra de Cayey consist mainly of shallow soil slips and debris flows with an average volume of 120 cubic meters and can number as many as 20 per square kilometer. The mass of eroded material can be as high as 6,000 metric tonnes per square kilometer. Because most of the soil eroded by landsliding is delivered directly to river channels, fluvial sediment loads can remain high for many months following large storms. For example, a single landslide that occurred during Hurricane Hortense in the Río Icacos watershed in El Yunque introduced a mass of soil into the river that is equivalent to the average annual sediment yield for an entire year. The geomorphic effects of such storms will be visible on hillslopes and river channels for decades in the form of altered hillslope form and channel morphology. These results provide land-use managers and public-safety agencies with an inexpensive method that can be used to assess landslide hazards in Puerto Rico.

\section{Beach Erosion and Coastal Development at Rincón, Puerto Rico}

A record of historical shoreline positions and erosion rates has been compiled for the area near Rincón, in western Puerto Rico, for 1950-94 (fig. 3). The study area includes approximately 8 kilometers of the northwestern coast, from Punta Higüero to Punta Cadena (fig. 4). Historical shoreline positions were obtained from aerial photographs. More recent shoreline position surveys were conducted using a portable, differential Global Positioning System.

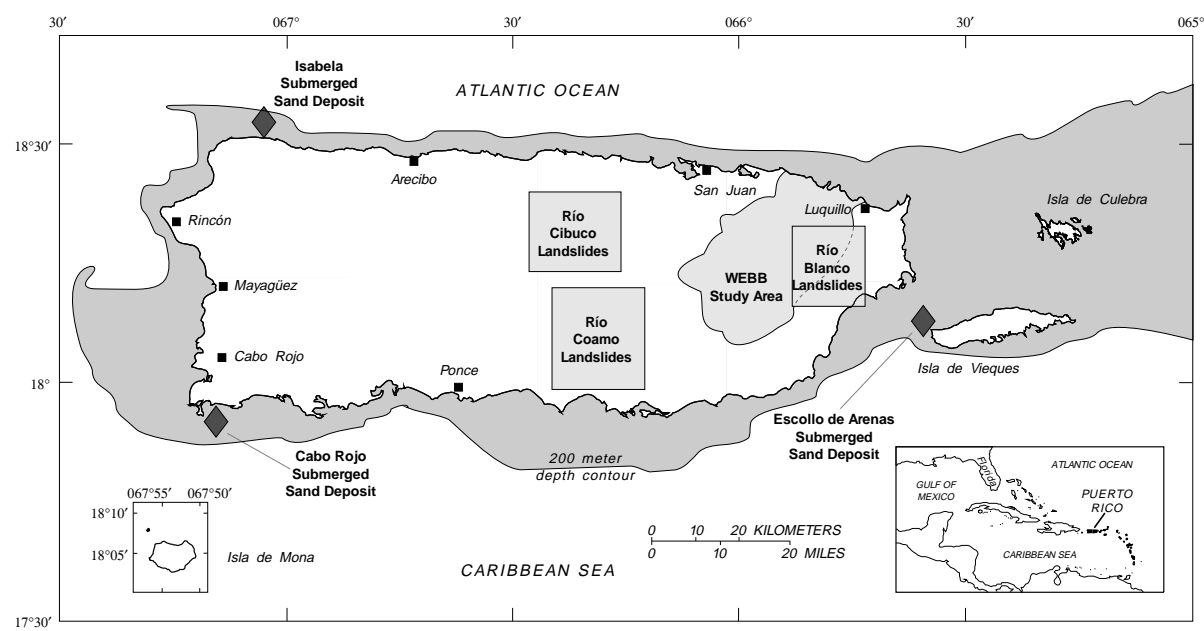

Figure 3. Location of Puerto Rico and various study sites.

Erosion rate data for Reach B indicate that there was a profound change in the historical trend between 1977 and 1987. Before 1977, the erosion rate in Reach B was about $0.5 \pm 0.3$ meters per year. From 1987 to 1994 , however, the erosion rate was more than $3.0 \pm 1.0$ meters per year. The increased erosion correlates with the 1983 construction of a relatively small marina within Reach B. Emplacement of a breakwater/jetty system and the continued removal of dredged material at the marina entrance appear to be the major contributing factors to the recent increase in erosion rates. Human response to the increased rate of shoreline erosion has been a piecemeal

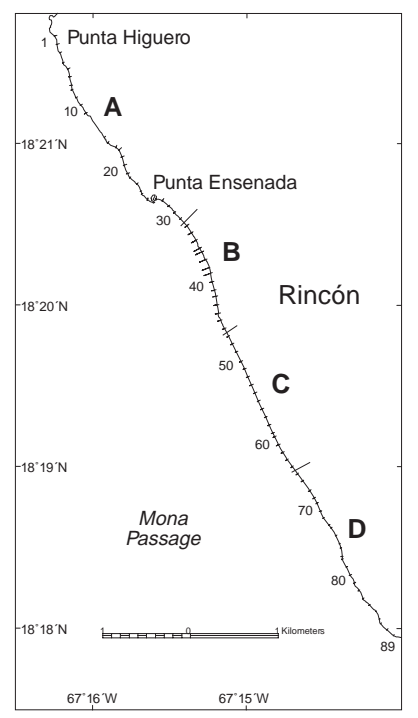

Figure 4. The shoreline in the study area was divided into four distinct reaches based on erosion rates. The relative magnitude of shoreline movement between 1950-1994 is depicted by the transect line length. seawalling of the shoreline. If left unmitigated, continuing shoreline stabilization with the piecemeal construction of seawalls and revetments may result in the rapid destruction of local beaches. Manmade stabilization structures also may reduce sediment supply to downdrift beaches, thus increasing the erosion of beaches that are used for recreation and tourism and that support a small, beach-based fishing fleet.

\section{Hydrologic Data Collection}

Since 1958, the USGS, in cooperation with 15 local and Federal agencies has been collecting a large amount of data pertaining to the water resources of Puerto Rico. These data constitute a valuable data base for developing an improved understanding of the water resources in Puerto Rico. These data include records on surface and ground water, water quality, and stream-sediment concentration and transport.

Surface water is a major source of drinking water, industrial supply, and irrigation in Puerto Rico. The surface-water data-collection program (fig. $5 B$ ) measures stream discharge and the amount of rain falling in specific river drainage basins. Water samples also are collected (fig. $5 A$ ) to determine the physical, chemical, and bacteriological characteristics of lakes, streams, and rivers.

Long-term monitoring of ground-water levels gives insight into the withdrawal and recharge rates of aquifers, and provides essential information for managing these important water resources. The USGS maintains a computer data base that contains information on the physical and chemical characteristics of water in about 5,700 wells and springs in Puerto Rico. 

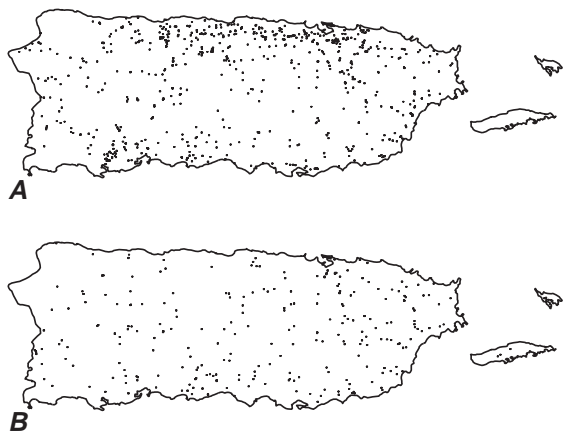

Figure 5. Water-quality $(A)$ and surface-water (B) data-collection sites throughout Puerto Rico.

\section{Floods and Droughts}

Floods can be extremely destructive in Puerto Rico because of the island's topography and dense population. Nearly 70 nonnavigable rivers and streams - whose banks and drainage areas are dotted with communities - originate in the central mountain range. The stream valleys are narrow, relatively short, and steep-features that make the streams susceptible to flooding, particularly flash flooding.

Flash floods typically result from rainfall that is intense in the upper basins but that is sparse or nonexistent on the coast. Streams on the south coast are more susceptible to flash flooding than those on the north coast because of their shorter length and steeper gradient. Lag time from the occurrence of intense rainfall to the peak discharge is, therefore, least along the southern coastal plain.

Large areas of the coastal plain are subject to storm-surge flooding from hurricanes and other tropical storms. The coastal plain also is vulnerable to flooding by large coastal sea swells generated by winter storms over the Atlantic Ocean.

Although drought can be defined as a period of deficit in rainfall or water supply for an extended period of time, there is no single commonly accepted measure of drought in terms of water demand. In fact, there is no quantitative definition of drought that is universally acceptable. Most of the criteria used to identify drought have been arbitrary because a drought is something of a nonevent, as opposed to a distinct event such as a flood. Drought has no distinct onset and is recognizable only after a period of time. In addition, this period of time is variable because the time required for a drought to develop depends on many interacting variables.

Table 1. Chronology of major and other memorable floods and droughts in Puerto Rico, 1899-1995

[Recurrence interval: The average interval of time within which streamflow will be greater than a particular value for floods or less than a particular value for droughts; recurrence intervals calculated from U.S. Geological Survey data; - , not determined]

\begin{tabular}{|l|l|l|c|}
\hline $\begin{array}{c}\text { Flood } \\
\text { or } \\
\text { Drought }\end{array}$ & \multicolumn{1}{|c|}{ Date Area affected } & $\begin{array}{c}\text { Recurrence } \\
\text { interval } \\
\text { (years) }\end{array}$ \\
\hline \hline Flood & Aug. 8,1899 & Islandwide & Unknown \\
\hline Flood & Sept. 13, 1928 & Islandwide & 100 \\
\hline Flood & Sept. 26, 1932 & Islandwide & Unknown \\
\hline Flood & Sept. 6, 1960 & Eastern Puerto Rico & 25 to 80 \\
\hline Flood & Aug. 27, 1961 & Northeastern Puerto Rico & 2 to 25 \\
\hline Flood & Dec. 9-11, 1965 & Interior and north coast & 2 to 25 \\
\hline Drought & $1966-68$ & Islandwide & 10 to 27 \\
\hline Flood & Nov. 9, 1969 & Eastern Puerto Rico & 2 to 10 \\
\hline Flood & Oct. 5-10,1970 & Eastern two-thirds of Puerto Rico & 2 to 50 \\
\hline Drought & $1971-74$ & Islandwide & 15 to 26 \\
\hline Flood & Sept. 16, 1975 & Southwestern Puerto Rico & 25 to 100 \\
\hline Drought & $1976-77$ & Islandwide & 5 to 28 \\
\hline Flood & Oct. 7, 1977 & Eastern Puerto Rico & 2 to 10 \\
\hline Flood & Oct. 26-27, 1978 & Southern and eastern Puerto Rico & 2 to 25 \\
\hline Flood & Aug. 29-31, 1979 & Eastern, southern, and northern Puerto Rico & 2 to 25 \\
\hline Flood & Sept. 4, 1979 & Northern and eastern Puerto Rico & 2 to 10 \\
\hline Flood & Sept. 12-13, 1982 & Southern Puerto Rico & 2 to 25 \\
\hline Flood & Nov. 3-5, 1984 & Eastern Puerto Rico & 2 to 10 \\
\hline Flood & May 17-18, 1985 & Northern and north-central Puerto Rico & 20 to 100 \\
\hline Flood & Oct. 6-7, 1985 & Southern Puerto Rico & >100 \\
\hline Flood & Jan. 5-6, 1992 & Northern and eastern Puerto Rico & - \\
\hline Drought & $1993-94$ & - & to 100 \\
\hline Flood & Sept. 9-10, 1996 & Eastern Puerto Rico & - \\
\hline
\end{tabular}

Historically, droughts are rare in Puerto Rico (table 1). Significant droughts in recent years that affected large areas of Puerto Rico over an extended period of time occurred during 1966-68, 1971-74, 1976-77, and 1993-94. The 1971-74 drought was the most severe drought on record in terms of streamflow deficits and duration, whereas the 1993-94 drought was most severe in terms of water-supply problems.

\section{Water, Energy, and Biogeochemical Budgets}

The humid tropics occupy 25 percent of the Earth's land surface and by the year 2000 will contain approximately 50 percent of the Earth's population. Rapid deforestation in the humid tropics is recognized as a threat to both the economic development of the affected areas and to global climate. Development stresses include major adverse effects on soils, soil nutrients, surface-water quality, reservoirs, and increase the shortterm hazards of landslides and floods. To understand these processes and provide information useful for developing solutions to these problems as they may affect Puerto Rico, the USGS has developed a long-term Water, Energy, and Biogeochemical Budget program (WEBB) research site in the Sierra de Luquillo in eastern Puerto Rico. The site consists of the 11,300-hectare U.S. Forest Service-administered Luquillo Experimental Forest and the Río Grande de Loíza drainage basin, an agriculturally developed watershed.

The research work focuses on tropical geomorphic and biogeochemical processes that control the movement and transformation of water, energy, bedrock weathering products, and nutrients in the earth-surface environment (fig. 6). Detailed data are being obtained on hillslope and fluvial transport and erosion processes, soil-development, 
and nutrient cycling. These data are being used to develop sediment and water budgets and a geomorphic model of tropical landform development. This model can assist resource managers in identifying planning solutions to reservoir sedimentation, landslides, floods, and other development-related geomorphic problems that occur in densely populated tropical settings.

\section{Topographic Mapping}

Among the most popular and versatile products of the USGS in Puerto Rico are its 1:20,000-scale topographic maps ( 1 inch on the map represents about 1,667 feet on the ground). These maps depict basic natural and cultural features of the landscape, such as mountains, lakes and streams, highways, boundaries, and geographic names. Contour lines are used to depict the elevation and shape of the terrain. Puerto Rico is covered by 67 , which are useful for civil engineering, land-use planning, natural-resource monitoring, and other technical applications. These maps have long been favorites with the general public for outdoor uses, including hiking, camping, and exploring.

\section{Geologic Mapping}

Geologic mapping of Puerto Rico is now largely complete at a scale of 1:20,000.

Work on compiling a digitized geologic map of Puerto Rico at a scale of 1:200,000 as well as numerous other derivative maps that deal with natural geologic economic resources and various mineral resources also is underway.

\section{Earth Observation Data}

Through its Earth Resources Observation Systems Data Center near Sioux Falls, South Dakota, the USGS distributes a variety of aerial photographs and satellite image data products that cover the entire island of Puerto Rico. Mapping photographs of some sites go back about 40 years. Satellite images dating from 1972 can be used to study changes in regional landscapes.

The USGS and the U.S. Environmental Protection Agency are cooperating to create computerized (digital) images from aerial mapping photographs of Puerto Rico. These digital images will form a seamless data set for a geographic information system useful for assessing potential hazards, such as oil spills and non-point pollution sources, related to water resources.
USGS state representative

GSA Center

51 Federal Drive, Suite 400-15

Guaynabo, PR 00965

(787) $749-4346$

Fax: (787) 749-4462

Email: dc_pr.usgs.gov

Additional earth science information can be found by accessing the USGS Home Page

on the World Wide Web at

http://www.usgs.gov/

For more information on all USGS reports and products (including maps, images, and computerized data), call 1-800-USA-MAPS

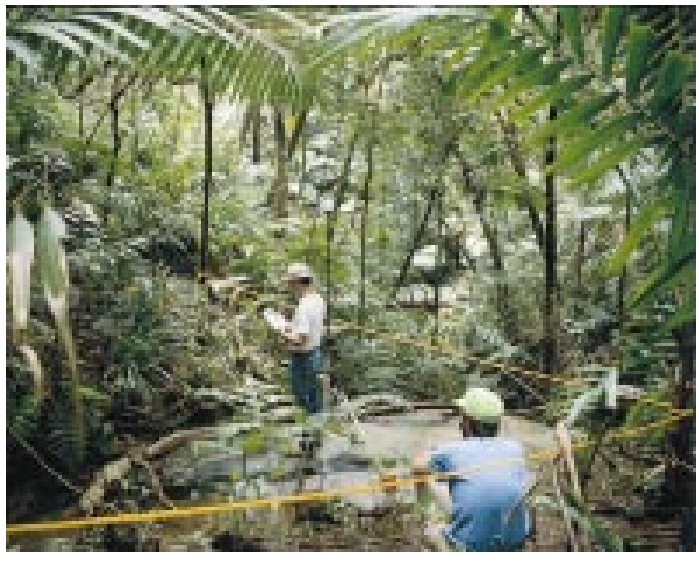

Figure 6. WEBB personnel mapping stream channels in the Luquillo Experimental Forest in northeastern Puerto Rico. Normal mapping techniques underrepresent stream networks in this tropical mountain setting due to the dense forest canopy, necessitating the use of Global Positioning System techniques to determine stream channel and headwater locations and extents.
The USGS provides maps, reports, and information to help others meet their needs to manage, develop, and protect America's water, energy, mineral, biological, and land resources. We help find the natural resources needed to build tomorrow, and supply the scientific understanding needed to help minimize or mitigate the effects of natural hazards and environmental damage caused by natural and human activities. The results of our efforts touch the daily life of almost every American. 